Homepage: http://epubs.icar.org.in/ejournal/index.php/JWR

\title{
Exogenous melatonin improves seedling vigour and drought tolerance in wheat
}

Rinki Khobra*, Mamrutha HM, Karnam Venkatesh, Chandra Nath Mishra, Raj Pal Meena, Sanjay Singh, Gyanendra Singh, Gyanendra Pratap Singh

ICAR-Indian Institute of Wheat and Barley Research, Karnal-132001, India

Article history: Received: 31 Aug., 2020 Revised: 7 Dec., 2020 Accepted: 19 Dec., 2020

Citation: Khobra R, HM Mamrutha, K Venkatesh, CN Mishra, RP Meena, SK Singh and GP Singh. 2020. Exogenous melatonin improves seedling vigour and drought tolerance in wheat. Journal of Cereal Research 12(3): 334-337. http:// doi.org/10.25174/2582-2675/2020/104152

*Corresponding author: E-mail:Rinki@icar.gov.in

(C) Society for Advancement of Wheat and Barley Research

Keywords: Wheat (Triticum aestivum L.), drought, melatonin, stress tolerance, growth regulator

Melatonin (N-acetyI-5-methoxytryptamine) is a ubiquitous growth regulator suggested as a promising molecule involved in abiotic stress tolerance. In the past few decades, research on melatonin was hastened to reveal its role in agricultural science (Arnao and Hernandez-Ruiz, 2015). Many studies have confirmed its significant role in seed germination, root and shoot growth regulation, growth stimulation and delaying induced leaf senescence under stress in different crops (Wang et al., 2013a; Shi et al., 2015a).Shi et al., (2015b) reported increased abiotic stress tolerance by increasing antioxidant activity and secondary metabolites in bermudagrass. However, many regulatory and functional roles of melatonin are still not understood completely in cereal crops like wheat (Ahmad et al., 2019). Hence, an experiment was conducted to study the effect of melatonin on Indian wheat genotypes with respect to shoot and root growth parameters under moisture deficit condition at seedling stage.

The experiment was conducted at ICAR-Indian Institute of Wheat and Barley Research, Karnal during crop season 2017-18 under controlled condition. Six wheat genotypes namely, C306, NI5439, HD3086, RW5, DBW136, WH147 were sown in two sets with three replications in the germination tray under drought stress condition. Melatonin treatment was given to one set of genotypes at GS 14, GS 22 growth stages according to Zadok's scale (Zadok's 1974) which generally coincides with seedling development stage and tillering initiation stage. The second set of genotypes was kept untreated based on the literature survey $100 \mu \mathrm{M}$ concentration of melatonin was considered as optimal for the experiment (Ye et al., 2016; Gao et al., 2018; Ahmad et al., 2019; Huang et al., 2019; Bai et al., 2020). Data was recorded for Chlorophyll content (SPAD), Normalized Difference Vegetation Index (NDVI) and Chlorophyll fluorescence (CFL) along with seedling growth related traits like shoot fresh weight, shoot dry weight, root fresh weight, root length on per plant basis. Analysis of variance and ranking of genotypes was done using Tukey's Studentized range test at 0.05 (5\%) level of significance. Pearson's correlation coefficient $(\mathrm{r})$ was used to indicate the interaction among the traits studied. All the statistical analysis were performed using JASP 0.12.1 statistical package (JASP Team, 2020).

Analysis of variance (Table-1) showed significant differences among the treatments for most of the traits like, SPAD, CFL, Shoot fresh weight, shoot dry weight and root fresh weight except for root to shoot ratio. The genotypes performed better under melatonin treatment for almost all parameters studied (except R:S ratio) compared to drought stress. This is in close compliance with those obtained by Ahmad et al., 2019. When the genotypes were compared for different physiological traits then more variation was found in melatonin treated set of wheat genotypes as compared to drought. Lower mean SPAD value (47.56) was recorded under drought condition as compared to melatonin treated (51.49) 
condition(Table-2). Chlorophyll fluorescence is the widely used most important mean for accessing the maximal photochemical efficiency of PSII (Zhou et al., 2010).Data recorded for CFL showed substantial impact of melatonin spray on wheat genotypes and the values were higher (0.809) as compared to drought (0.803). The similar results were also reported by Ye et al, 2016.

In case of plant growth related traits, overall increase in plant weight (root and shoot) was observed under melatonin treated condition as compared to drought. The mean shoot fresh weight under drought stress was $0.974 \mathrm{~g}$ however under treated set of genotypes the values were $1.44 \mathrm{~g}$. The same trend was followed for root fresh weight for the genotypes under untreated $(0.405 \mathrm{~g})$ and treated $(0.478 \mathrm{~g})$ conditions (Table-2). Melatonin also effected the growth in root length and the mean root length under treated $(18.02 \mathrm{~cm})$ condition was higher as compared to the drought $(15.27 \mathrm{~cm})$ condition (Table-2). Ye et al (2016) also reported the better rooting as well as root water uptake efficiency under drought due to melatonin application in maize seedlings.

Two-way ANOVA revealed that, in the treated set of wheat genotypes no significant difference has been recorded for SPAD values among the genotypes except DBW 136 which was significantly low value (45.86). However, among the genotypes under drought condition C306 was having highest chlorophyll content (50.36) while DBW136 showed lowest SPAD value (42.83).

The presence of significant genotypic differences among the studied genotypes was observed for SPAD and root fresh weight under drought while SPAD, CFL and Shoot dry weight under treated conditions (Table-2). The observations revealed that higher CFL values were recorded for C306(0.813), HD3086 (0.813) and DBW136 (0.812) followed by NI5439(0.808) under melatonin treated set. While in drought condition DBW136 (0.800) has showed minimum CFL value and no significant difference was recorded for other genotypes. RW5 (0.803)

Table 1. ANOVA for different physiological and plant growth traits in six wheat genotypes

\begin{tabular}{lllllllllll}
\hline $\begin{array}{l}\text { Source of varia- } \\
\text { tion }\end{array}$ & df & SPAD & NDVI & CFL & \multicolumn{2}{l}{$\begin{array}{l}\text { Shoot Fresh } \\
\text { Wt }\end{array}$} & $\begin{array}{l}\text { Shoot Dry } \\
\text { Wt }\end{array}$ & $\begin{array}{c}\text { Root Length } \\
\text { Root Fresh } \\
\text { Wt }\end{array}$ \\
\hline Treat & 1 & $<.001$ & 0.001 & $<.001$ & $<.001$ & $<.001$ & 0.006 & $<.001$ \\
gen & 5 & $<.001$ & 0.035 & 0.001 & 0.048 & 0.002 & 0.032 & 0.010 \\
Treat gen & 5 & 0.851 & 0.760 & $<.001$ & 0.390 & 0.297 & 0.797 & 0.999 \\
\hline
\end{tabular}

Table 2. Comparative effect of melatonin on different physiological and plant growth traits in wheat genotypes under drought and treated conditions

\begin{tabular}{|c|c|c|c|c|c|c|c|c|c|}
\hline Treatment & Genotypes & SPAD & NDVI & CFL & $\begin{array}{l}\text { Shoot Fresh } \\
\text { Wt }(g)\end{array}$ & $\begin{array}{l}\text { Shoot Dry } \\
\text { Wt }(g)\end{array}$ & $\begin{array}{l}\text { Root Length } \\
\mathrm{cm}\end{array}$ & $\begin{array}{l}\text { Root fresh } \\
\text { Wt }(g)\end{array}$ & R:S Ratio \\
\hline \multirow[t]{6}{*}{ Drought } & C306 & $50.367^{\mathrm{aAB}}$ & $0.227^{\mathrm{aA}}$ & $0.804^{\mathrm{aBC}}$ & $0.880^{\mathrm{aB}}$ & $0.490^{\mathrm{aB}}$ & $16.26^{\mathrm{aAB}}$ & $0.497^{\mathrm{aABC}}$ & $0.563^{\mathrm{aA}}$ \\
\hline & DBW136 & $42.833^{\mathrm{bC}}$ & $0.197^{\mathrm{aA}}$ & $0.800^{\mathrm{aC}}$ & $1.157^{\mathrm{aAB}}$ & $0.843^{\mathrm{aB}}$ & $15.63^{\mathrm{aAB}}$ & $0.441^{\mathrm{abABC}}$ & $0.387^{\mathrm{aAB}}$ \\
\hline & HD3086 & $47.667^{\mathrm{abABC}}$ & $0.247^{\mathrm{aA}}$ & $0.804^{\mathrm{aBC}}$ & $1.043^{\mathrm{aB}}$ & $0.643^{\mathrm{aB}}$ & $16.20^{\mathrm{aAB}}$ & $0.379^{\mathrm{abABC}}$ & $0.367^{\mathrm{aAB}}$ \\
\hline & NI5439 & $48.767^{\mathrm{abABC}}$ & $0.233^{\mathrm{aA}}$ & $0.804^{\mathrm{aBC}}$ & $0.890^{\mathrm{aB}}$ & $0.517^{\mathrm{aB}}$ & $16.76^{\mathrm{aAB}}$ & $0.407^{\mathrm{abABC}}$ & $0.463^{\mathrm{aAB}}$ \\
\hline & RW5 & $48.833^{\mathrm{abABC}}$ & $0.197^{\mathrm{aA}}$ & $0.802^{\mathrm{aBC}}$ & $1.010^{\mathrm{aB}}$ & $0.667^{\mathrm{aB}}$ & $14.13^{\mathrm{aAB}}$ & $0.365^{\mathrm{abBC}}$ & $0.360^{\mathrm{aAB}}$ \\
\hline & WH147 & $46.900^{\mathrm{abABC}}$ & $0.217^{\mathrm{aA}}$ & $0.803^{\mathrm{aBC}}$ & $0.863^{\mathrm{aB}}$ & $0.587^{\mathrm{aB}}$ & $12.66^{\mathrm{aB}}$ & $0.340^{\mathrm{bC}}$ & $0.390^{\mathrm{aAB}}$ \\
\hline Mean & & 47.56 & 0.22 & 0.803 & 0.974 & 0.625 & 15.27 & 0.405 & 0.42 \\
\hline \multirow{6}{*}{$\begin{array}{l}\text { Drought+ } \\
\text { Melatonin } \\
\text { treatment }\end{array}$} & C306 & $52.700^{\mathrm{aA}}$ & $0.280^{\mathrm{aA}}$ & $0.813^{\mathrm{aA}}$ & $1.317^{\mathrm{aAB}}$ & $0.837^{\text {bв }}$ & $20.40^{\mathrm{aAB}}$ & $0.553^{\mathrm{aA}}$ & $0.433^{\mathrm{aAB}}$ \\
\hline & DBW136 & $45.867^{\mathrm{bBC}}$ & $0.223^{\mathrm{aA}}$ & $0.812^{\mathrm{aA}}$ & $2.007^{\mathrm{aA}}$ & $1.630^{\mathrm{aA}}$ & $16.83^{\mathrm{aAB}}$ & $0.545^{\mathrm{aAB}}$ & $0.273^{\mathrm{aB}}$ \\
\hline & HD3086 & $53.100^{\mathrm{aA}}$ & $0.277^{\mathrm{aA}}$ & $0.813^{\mathrm{aA}}$ & $1.123^{\mathrm{aB}}$ & $0.800^{\mathrm{bB}}$ & $17.40^{\mathrm{aAB}}$ & $0.473^{\mathrm{aABC}}$ & $0.433^{\mathrm{aAB}}$ \\
\hline & NI5439 & $52.867^{\mathrm{aA}}$ & $0.270^{\mathrm{aA}}$ & $0.808^{\mathrm{abAB}}$ & $1.437^{\mathrm{aAB}}$ & $0.923^{\mathrm{abB}}$ & $21.73 \mathrm{aA}$ & $0.490^{\mathrm{aABC}}$ & $0.377^{\mathrm{aAB}}$ \\
\hline & RW5 & $53.000^{\mathrm{aA}}$ & $0.257^{\mathrm{aA}}$ & $0.803^{\mathrm{bBC}}$ & $1.453^{\mathrm{aAB}}$ & $1.167^{\mathrm{abAB}}$ & $16.50^{\mathrm{aAB}}$ & $0.424^{\mathrm{aABC}}$ & $0.347^{\mathrm{aAB}}$ \\
\hline & WH147 & $51.400^{\mathrm{aAB}}$ & $0.230^{\mathrm{aA}}$ & $0.802^{\mathrm{bBC}}$ & $1.307^{\mathrm{aAB}}$ & $0.877^{\mathrm{abB}}$ & $15.30^{\mathrm{aAB}}$ & $0.385^{\mathrm{aABC}}$ & $0.350^{\mathrm{aAB}}$ \\
\hline Mean & & 51.49 & 0.26 & 0.809 & 1.44 & 1.03 & 18.02 & 0.478 & 0.36 \\
\hline
\end{tabular}

Mean values that do not share a letter (small: Within treatment, Capital: across treatments) are significantly different at $\mathrm{p}=<0.05$ 
and WH147 (0.802) did not show any differential effect of melatonin treatment for CFL values.

Among the genotypes highest shoot fresh weight was obtained by DBW136 (2.007g) followed by RW5 (1.453g) under melatonin treatment and the same trend was observed for shoot fresh weight under drought. Under melatonin treated condition, DBW136 also recorded the maximum shoot dry weight $(1.630 \mathrm{~g})$ followed by RW5 (1.167g) and NI5439 (0.923g), but there was no significant difference observed among genotypes under drought environment.Minimum root length and root weight under drought was recorded for WH147 $(12.66 \mathrm{~cm}$ and $0.340 \mathrm{~g})$ while others were at par with each other. But under melatonin treatment maximum root length was obtained

\section{References}

1. Ahmad S, M Kamran, R Ding, X Meng, H Wang, I Ahmad, S Fahad, QHan. 2019. Exogenous melatonin confers drought stress by promoting plant growth, photosynthetic capacity and antioxidant defense system of maize seedlings. PeerJ 7: e7793

2. Arnao Mand Hernández-Ruiz J. 2015. Functions of melatonin in plants: A Review. Journal of Pineal Research 59. 10.1111/jpi.12253.

3. Bai Y, S Xiao, Z Zhang, Y Zhang, H Sun, K Zhang, X Wang, Z Bai, C Li, L Liu L. 2020. Melatonin improves the germination rate of cotton seeds under drought stress by opening pores in the seed coat. PeerJ 8: e9450

4. Cui G, X Zhao, S Liu, F Sun, C Zhang, Y Xi. 2017. Beneficial effects of melatonin in overcoming drought stress in wheat seedlings. Plant Physiology and Biochemistry 118:138-149

5. FAO. 2019. The State of Food and Agriculture 2019. Moving forward on food loss and waste reduction. Rome. Licence: CC BY-NC-SA 3.0 IGO

6. Gao W, Y Zhang, Z Feng, Q Bai, J He, Y Wang. 2018. Effects of melatonin on antioxidant capacity in naked oat seedlings under drought stress. Molecules 23:1580

7. Hernández-Ruiz J, A Cano and MB Arnao. 2005. Melatonin acts as a growth-stimulating compound in some monocot species. Journal of Pineal Research 39: 137-142. by $\mathrm{NI} 5439(21.73 \mathrm{~cm})$. Although C306 $(20.40 \mathrm{~cm})$ was succeeded by NI5439 $(21.73 \mathrm{~cm})$ in terms of root length but it maintained highest root fresh weight when treated with melatonin.

The results highlighted that melatonin application improved seedling vigour, and other morpho-physiological traits along with overall plant performance as compared to the non-treated set of wheat seedlings under drought stress. Though, the experiment is preliminary at seedling stage but the results are promising. However, the research findings entail that melatonin can improve drought stress tolerance and could be considered as a potential growth regulator for yield improvement in arid and semi arid areas.

8. Huang B, YE Chen, YQZhao, CB Ding, JQ Liao, C $\mathrm{Hu}, \mathrm{LJ}$ Zhou, ZW Zhang, S Yuan and M Yuan. 2019. Exogenous melatonin alleviates oxidative damages and protects photosystem II in maize seedlings under drought stress. Frontiers in Plant Science 10:677.

9. Leff B, N Ramankutty and JA Foley. 2004. Geographic distribution of major crops across the world. Global Biogeochemical Cycles 18: GB1009

10. Naeem M, MS Naeem, R Ahmad, R Ahmad, MY Ashraf, MZ Ihsan, F Nawaz, HURR Athar, M Ashraf, HT Abbas, M Abdullah. 2018. Improving drought tolerance in maize by foliar application of boron: water status, antioxidative defense and photosynthetic capacity. Archives of Agronomy and Soil Science 64: 626-639.

11. Posmyk MM and K Szafranska. 2016. Biostimulators: A new trend towards solving an old problem. Frontiers in Plant Science 61:571-578.

12. Shi H, RJ Reiter, DX Tan and Z Chan. 2015a. INDOLE-3-ACETIC ACID INDUCIBLE 17 positively modulates natural leaf senescence through melatonin-mediated pathway in Arabidopsis. Journal of Pineal Research 58:26-33.

13. Shi H, C Jiang, T Ye, DX Tan, RJ Reiter, H Zhang, R Lui, Z Chan. 2015b. Comparative physiological, metabolomic, and transcriptomic analyses reveal mechanisms of improved abiotic stress resistance 
in bermudagrass [Cynodondactylon (L). Pers.] by exogenous melatonin. Journal of Experimental Botany 66: $681-694$.

14. Wang P, X Sun, C Chang, F Feng, D Liang, L Cheng L, et al. 2013a. Delay in leaf senescence of Malus hupehensis by long-term melatonin application is associated with its regulation of metabolic status and protein degradation. Journal of Pineal Research 55: 424-434. 10.1111/jpi.12091

15. Ye J, W Yang, Y Li, S Wang, L Yin and X Deng. 2020. Seed pre-soaking with melatonin improves wheat yield by delaying leaf senescence and promoting root development. Agronomy 10: 84.

16. Ye J, S Wang, X Deng, L Yin, B Xiong, X Wang. 2016 Melatonin increased maize (Zea mays L.) seedling drought tolerance by alleviating drought-induced photosynthetic inhibition and oxidative damage. Acta Physiologiae Plantarum 38: 48.

17. Zadoks JC, TT Chang, CK Konzak. 1974. A decimal code for growth stage of cereals. Weed Research 14: 415-421.

18. Zhou SB, K Liu, D Zhang, QF Li, GP Zhu. 2010. Photosynthetic performance of Lycorisradiata var. radiate to shade treatments. Photosynthetica 48:241248. 